\title{
PLEASE READ WHILE TEXTING AND DRIVING
}

\author{
C. Edward Watson \\ Virginia Tech \\ Krista P. Terry \\ Appalachian State University \\ Peter E. Doolittle \\ Virginia Tech
}

Over the past decade, an argument has been made and perpetuated regarding changes in the learning profile of today's students that includes new multitasking abilities. The belief in these skills bas led some to encourage pedagogies that require multitasking. This chapter considers the lineage of the multitasking narrative, examines empirical research associated with multitasking, and charts a path forward for faculty, students, and developers to improve learning.

o

Faculty developers typically encourage instructors to engage in the process of learner analysis as they develop or revise learning modules, courses, or curriculum (Gustafson \& Branch, 1997). However, as faculty seek to learn more about their students, especially at the undergraduate level, they discover a pervasive thread in the literature speaking to generational cohort conceptions of learners, those often called millennials (or Net Geners, Generation Y, and digital natives). Howe and Strauss (2000), researchers 
focusing on generation-based conceptions across various facets of society, define millennials as those born after 1982. Regardless of disciplinary focus, compelling accounts of learner characteristics said to be unique to millennial students have emerged over the past ten years and permeate popular narratives regarding teaching, learning, and performance.

Key among the millennials' traits often linked to education and educational settings is the idea of today's students as multitaskers. Multitasking, a term originally referring to a computer system performing two or more tasks concurrently, now also commonly refers to individuals who engage in multiple activities as once. It is often said that "multitasking is a way of life for this generation" (McGlynn, 2005, p. 20). However, a number of questions emerge for those who reflect on this assumption within higher education. Specifically, how accurate is this generalization? What do we really know about the human capacity for multitasking? How well can students multitask? Given the answers to these questions, what are the implications of what we know for faculty development and faculty practice?

\section{The Making of a Myth}

When one considers the breadth of research regarding learning, it is truly astonishing how quickly beliefs about student multitasking have spread over the past decade. The foundation for these beliefs is that students are tabulae rasae who have been nurtured and shaped by digital technologies (Pletka, 2007). Diverse areas in the literature echo that same sentiment. For example, an article on faculty development in Nurse Educator reported that "millennials have grown up in an environment that is enhanced by multiple forms of media so they have become adept at multitasking" (Mangold, 2007, p. 22). Hispanic Outlook in Higher Education warned about student attention spans due to their multitasking strengths (McGlynn, 2005). Papers published in Innovate: Journal of Online Education discuss these strengths and describe habitual student multitasking as a notable characteristic of their learning style (Barnes, Marateo, \& Ferris, 2007; Sontag, 2009). Some have gone as far as to develop a new teaching paradigm predicated specifically on the belief that all students now possess these capabilities (Simon, 2005).

Certainly the popular media have played a role in perpetuating this conception of today's students. Time provided an in-depth discussion of what it termed the "multitasking generation" (Wallis, 2006), the Chronicle of Higher Education reported on multitasking characteristics of students (Carlson, 2005), and these perceptions have been echoed in other mass media contexts (Aratani, 2007; Oser, 2005). Most youth 
culture multitasking narratives ultimately reference the same small set of articles, and the commonality in this collection is the belief that technology has changed students' cognitive capacities.

Although never fulfilled as dramatically as described, there is a long history of predictions that stated technology would revolutionize learning and education in astonishing ways (see Saettler, 1968). It was predicted that radios would one day be present in every classroom, movies would replace books, and even B. F. Skinner suggested that the future would produce teaching machines that would double how much students could learn in a given time period (Seidensticker, 2006). More recently, Harel (1991) suggested that technological, constructivist-based activities could be the major leading factors in learning and cognitive development once such activities became widely available. This forecast was made the same year that the World Wide Web was launched and seemed to set the stage for the connections many would make regarding changes in student learning as a result of technology.

Throughout the 1990 s, student behaviors associated with the Web and a variety of electronic devices were increasingly observable, and Tapscott (1998), a social software business executive, was among the first to chronicle them. Thoughtful, though often anecdotal, his book speaks of multitasking and the impact it may be having on student attention spans. In 2000, Jason Frand, then director of computing and information services in the Anderson School of Management at UCLA, shared his observations regarding an emerging information age mind-set, which, he said, "only a small number of students" possessed at that time (Frand, 2000, p. 16). A key characteristic of this emerging mind-set was the "multitasking way of life" (p. 18). He predicted the number of students possessing this mind-set would increase over time. However, no data collection or analysis was performed to empirically support either his current perception of students or his prediction for the future. The following year, Marc Prensky, a video game developer, coined the term digital native (2001). Without any data or research to support his statements, he offered confident observations about students, including how "digital natives accustomed to the twitch-speed, multitasking, random-access, graphics-first, active, connected, fun, fantasy, quick-payoff world of their video games, MTV, and Internet are bored by most of today's education, well meaning as it may be" (p. 5).

Tapscott, Frand, and Prensky comprise the core set of common citations typically found across the students-as-multitaskers literature; however, it is important to note that none of these citations are supported by qualitative or quantitative research or data. Think pieces such as these 
often serve a key purpose in the development of scholarship as they posit foundations for hypotheses and research questions that are then vetted through empirical research. Interestingly, it appears these observations and predictions transitioned to facts about students simply through multiple citations. Frand's own qualifications regarding the small number of students possessing multitasking capacities did not follow in other citations. Diana Oblinger in EDUCAUSE Review, citing Frand, attributed multitasking to "students who have grown up with technology" (2003, p. 40). While Frand's initial supposition was questionable and in need of validation, Oblinger's new framing offered a generalization that applied to most college students-a significant and oft-cited leap forward for the multitasker mythology.

In the early to mid-2000s, addressing issues associated with educating the millennials became a priority for EDUCAUSE, a nonprofit group whose mission is "to advance higher education by promoting the intelligent use of information technology" through teaching, learning, research, advocacy, and faculty development (EDUCAUSE, 2010). EDUCAUSE Quarterly published Dede's "Planning for Neomillennial Learning Styles" during this time (2005a). Multitasking is accepted as an authentic student trait in his narrative, and his discussion moves beyond descriptions of millennials to explore appropriate pedagogies for multitaskers. Technology is married to instruction throughout, and the following guiding observation is made: "Whether multitasking results in a superficial, easily distracted style of gaining information or a sophisticated form of synthesizing new insights depends on the ways in which this learning strategy is used" (p. 7). That same year, Dede (2005b) provided his own predictions regarding how the emergence of this new learning style might influence higher education. In it, he specifically cited a cognition dimension where learners would be moving away from "sequential assimilation of linear information stream" toward "multitasking among disparate experiences and information sources" (p. 15.18). Dede states that a variety of changes in technology and student populations, including their burgeoning multitasking abilities, ultimate necessitate shifts in faculty development that may involve faculty unlearning "unconscious beliefs, assumptions, and values about the nature of teaching, learning, and the academy" (p. 15.16).

These quotations are taken from Educating the Net Generation, a freely available online edited book self-published by EDUCAUSE. Multitasking is a recursive theme across multiple chapters of this text, and the Tapscott, Frand, and Prensky viewpoints are either echoed or are foundational to the discussion. One chapter's conclusion begins, "The net 
generation possesses sophisticated technological adaptability and a remarkable capacity to incorporate multitasking into day-to-day academic activities" (Hartman, Moskal, \& Dziuban, 2005, p. 6.11). Unfortunately, there are few or even no reliable and valid data to support this claim that millennial students effectively multitask on a daily basis. These types of claims within the multitasking narrative tend to be supported by anecdotal evidence, self-report surveys, and misconceptions of what multitasking is. There is a need to move beyond reporting multitasking anecdotes and self-reports to examining and acting on multitasking in a rigorous, research-based manner.

Ultimately a great deal of inquiry is missing from this multitasking discussion, and while new books continue to tout students' multitasking and technological prowess (Jackson, 2008; Palfrey \& Gasser, 2008; Tapscott, 2009), it is premature to suggest that faculty should unlearn their beliefs about teaching and learning. This is also not to say that there is a void associated with multitasking research; rather, this research has yet to be connected to the current narrative. It is this research that lays bare the mythology surrounding multitasking-students of the millennial generation are effective multitaskers-that threatens to lead higher education teaching and learning astray.

\section{What Research Tells Us About Multitasking}

Given that the literature addressing millennial students posits, without reference to scientific evidence, multitasking as a core attribute, it is essential to take a step back and examine the literature on multitasking so as to inform the discussion. It should be noted that over the past century of research, different terms have been used-dual-task performance, split attention, divided attention, and multitasking - to describe addressing an individual's ability to process and act on two or more streams of information, stimuli, or tasks. In this chapter, we use multitasking to describe what researchers may have originally termed dual-task performance or split attention.

The research on multitasking is extensive (see Charron $\&$ Koechlin, 2010; Fitts \& Simon, 1952; Stager \& Zufelt, 1972; Tombu et al., 2011); however, the results are notably consistent: when individuals perform a secondary task (such as studying for a test) during the performance of a primary task (such as watching a movie), the secondary task performance is degraded (Pashler, 1994). This degradation of performance is based on two attentional bottlenecks: the encoding bottleneck and the response selection bottleneck (Dux \& Marois, 2009; Tombu \& Jolicoeur, 2003). 
The encoding bottleneck occurs when an individual attempts to encode into working memory a second task (or information set) while already processing a (first) task. The attention necessary to encode the first task hinders, or obstructs, the individual's ability to attend to and encode a second task. The response selection bottleneck occurs when an individual is asked to respond to two separate tasks. The attention necessary to select and implement the first response hinders, or obstructs, the individual's ability to attend to and select the second response. Thus, the more attentional resources a set of multiple tasks requires, the poorer the overall performance (especially of the subsequent tasks) will be.

Early discussions of multitasking began with philosophical observations-"the greater the number of objects to which our consciousness is simultaneously extended, the smaller is the intensity with which it is able to consider each" (Hamilton, Mansel, \& Veitch, 1861, p. 164)-followed by behavioral observations that attention may be focused in two places at once (Angell \& Moore, 1896; Hylan, 1903). These discussions developed into attempts to measure the degree to which an individual could attend to only a single task (clearness) or multiple tasks (vagueness). Geissler (1909) had participants attend to either a single task, marking a circle among distracters, or a dual task, marking a circle among distracters while simultaneously spelling challenging words or reciting lines of poetry. Following both the single and dual tasks, participants introspectively rated their "clearness" in attending, that is, their ability to focus their attention on the primary task. Geissler found that clearness was highly correlated with task type, such that single tasks were rated as being attended to more clearly than dual tasks. This focus on clearness, as a measure of attentional fidelity, then progressed to the use of reaction time. Cassel and Dallenbach (1918) used reaction time as an indicator of attention and determined that intermittent attentional distractions (a second attentional focus) led to decreases in reaction time performance. These early studies of attention and multitasking expanded over the following decades into discrete dual-task studies.

These dual-task studies resulted in a broad conclusion that "basic limits in doing two or more things at once seem to be a fundamental aspect of human performance" (Johnson \& Proctor, 2004, p. 190). These studies typically required individuals to attend to and respond to a primary task (saying "high" or "low" on hearing a high- or low-pitched tone), while simultaneously attending to and responding to a secondary task (tapping a blue or white button on seeing a square on a screen that is either blue or white). The results of primary-secondary multitasking studies indicate that when the two tasks occur simultaneously, responding to the second task is significantly impaired; but if the onset of the secondary task is 
delayed, such that the primary task occurs and then the secondary task occurs, the magnitude of the impairment relative to responding to the second task is decreased (Broadbent, 1965; Ostry, Moray, \& Marks, 1976; Pashler, 1993; Smith, 1967; Welford, 1952). One caveat to this reliable finding is that which task is considered "primary" is not always clear and is subject to the goals and decision making of the individual (Ruthruff, Pashler, \& Hazeltine, 2003). For example, in studies of driving (Levy, Pashler, \& Boer, 2006; Strayer \& Johnston, 2001) where an individual is completing a second task (using a cell phone, texting, selecting a song from an MP3 player, adjusting the radio), driving performance is reliably impaired through, for example, reduced reaction time, failure to see stop lights, or poor steering control. While it might be assumed that driving would be the primary task during driving, it is evident that when individuals choose to text while driving, creating and sending the text becomes the primary task.

More recently, new methods for examining multitasking, beyond behavioral performance, have emerged that shine additional light on the effects of multitasking on learning and performance. Ophir, Nass, and Wagner (2009) compared heavy media multitaskers (HMM: individuals who tend to use several different media simultaneously) and light media multitaskers (LMM) on several measures of cognitive control. They determined that "heavy media multitaskers are distracted by the multiple streams of media they are consuming or, alternatively, that those who infrequently multitask are more effective at volitionally allocating their attention in the face of distractions" (p. 3). Ophir et al. indicate that it is unclear if this breadth bias, casting a wide but shallow net on information rather than a more narrowly focused net, represents a persistent individual difference or a learner strategy.

In addition to this cognitive approach, new technology is being employed to identify the regions of the brain that are activated under multitasking conditions and the structural limitations that exist when an individual attempts to perform multiple tasks at once. One such study (Charron \& Koechlin, 2010), using functional magnetic resonance imaging (fMRI), employed a standard cognitive task of backward letter matching and emulated single- and dual-task conditions to discern which areas of participants' brains were activated during both the single- and dual-task performance scenarios. Their findings indicate that while frontal lobes work concurrently under single-task conditions, they divide during dual-task conditions, with one lobe supporting one task and the other supporting the second task. This supports a capacity-limit theory and indicates that this capacity limit "places a severe constraint bearing upon human higher cognition and may clarify several limitations in human 
decision-making and reasoning abilities" (p. 363). In addition, they hypothesized, and then affirmed, that given the split in resources tested during dual-task performances, "the frontal function is unable to accurately drive more than two concurrent tasks at one time" (p. 363).

These behavioral, cognitive, and neurological studies provide evidence that individuals can multitask (focus on two tasks simultaneously) but that multitasking leads to impaired cognition and performance. Can individuals multitask? Yes. Can students of the millennial generation multitask effectively? No.

So what does multitasking look like in the real world? Several studies related to laptop use during lectures have reported that the more students attempt to multitask during lectures, the more their academic performance is negatively affected (Fried, 2008; Kraushaar \& Novak, 2006; Wood et al., 2012). In addition, a survey that asked students to report on their instant messaging (IM) activities found that students who reported IMing or doing other similar multitasking activities while doing homework reported a higher level of academic impairment than those who did not (Junco \& Cotten, 2011). IMing has also been significantly related to higher levels of academic distractibility for academic tasks (Levine, Waite, \& Bowman, 2007), which would infer that a degradation of performance would follow suit.

Although some evidence exists that practice may lessen the impact of the performance-limiting bottleneck (Dux et al., 2009; Schumacher et al., 2001), questions remain as to how extensive practicing needs to be to do so, what types of tasks (for example, motor versus cognitive tasks) can be susceptible to enhanced performance (Hiraga, Garry, Carson, \& Summers, 2009), and to what extent the bottleneck can be completely eliminated (Van Selst, Ruthruff, \& Johnston, 1999). The lingering questions about conditions under which multitasking may be able to be achieved do little to negate the well-established body of literature that speaks to definite limitations, and resultant consequences, of attempting to divide attention between more than one task at a time. This brings into question the claims that the millennial generation, just by virtue of having access to more technology and more information sources, is de facto adept at performing multiple tasks at once.

\section{Conclusions and Recommendations}

The writings of Tapscott (1998), Frand (2000), and Prensky (2001) gave voice to the notion of students as effective and efficient multitaskers. This multitasking meme was fed and nourished by subsequent authors 
(McGlynn, 2005; Sontag, 2009; Wallis, 2006) such that myth became legend and legend became truth: students are multitaskers. The evidentiary truth about multitasking is in the empirical studies described above: humans lack the cognitive, behavioral, and neurological structures necessary to multitask effectively. Specifically, as we begin to engage two tasks simultaneously, the quality of the performance of the two tasks is reduced, and attempting three tasks simultaneously is chaotic. If multitasking, regardless of modern convention, is more myth than reality, how should faculty, administrators, and students respond?

The following five recommendations, based on what we empirically know regarding multitasking, provide guidance for addressing multitasking in academic life:

1. Students and faculty need to be conscious of multitasking: what it is, when it occurs, and what the ramifications are. The beginning point of dealing with multitasking is an awareness of what multitasking is and the impact it has on cognitive and behavioral performance. Ultimately this would require that students gain a better understanding of their own metacognition and that teachers gain a better understanding of students' metacognitive awareness and control. Metacognitive awareness represents one's recognition of one's own knowledge and skills and when to apply that knowledge and skill. Metacognitive control represents one's ability to plan a course of action (cognitive or physical), monitor the progress of that action, and evaluate the results of that action. Students rarely are taught these basic mechanics of learning; however, a first-year experience or a student orientation with a component on learning could provide students with information regarding the nature of multitasking, the outcomes of multitasking, and strategies for dealing with multitasking. Faculty members often have little understanding of these concepts as well; thus, these concepts could be incorporated and revisited in appropriate faculty development events.

2. Students need to self-regulate in creating nonmultitasking environments in which to learn and perform. The process of self-creating nonmultitasking learning environments builds off the first recommendation that students are self-aware of the ill effects of multitasking. Once students are self-aware of multitasking, they can begin the process of controlling it. This control, or self-regulation, would include (1) observing oneself in various situations in order to become more aware of when one tends to multitask; (2) avoiding multitasking distractions in class (such as Facebook, texting, talking, and reading) and not bringing potential distractions to class (a computer, cell phone, newspaper, magazine, and 
so on); and (3) avoiding multitasking distractions when studying, completing course projects, and other out-of-class activities (Zimmerman, Bonner, \& Kovach, 1996).

3. Teachers should provide students with scaffolding in circumstances where multitasking is likely to occur. As students engage in the processes of becoming aware of multitasking and learning to control it, teachers must also play an active part in recognizing and mediating multitasking. Multitasking represents an overload of an individual's working memory capacity-processing and storage. One avenue for ameliorating that overload is to provide students with scaffolds, from copies of diagrams and graphs to be discussed in class, to directions and pictures for completing procedures, to instructional strategies that foster simple to complex learning. Reiser (2004), in examining technologically based scaffolding within educationally relevant technological tools and activities, decomposes scaffolding into the subcomponents of structuring and problematizing, where structuring refers to simplifying complex cognitive tasks in order to make the task more tractable, and problematizing refers to directing learners' attention toward complex issues or characteristics of the task that might otherwise be overlooked. It is important to note that while Reiser's structuring is designed to simplify a task, problematizing is designed to make sure that learners engage in the complexity within that simplified task, "to guide the learner into facing complexity in the domain that will be productive for learning" (p. 288).

4. Teachers should foster automaticity to reduce the effects of multitasking. Students' ability to multitask effectively increases when the tasks to be completed are automated; thus, teachers should provide students with opportunities to engage in, experience, and practice tasks to foster automaticity and expect that advanced students (seniors and graduate students) will be able to multitask somewhat better than novice students (first-year students). In addition, given that seniors and graduate students should have greater experience with certain knowledge and skills, these students should be able to multitask more effectively based on more automated knowledge and skills (Dux et al., 2009).

5. Teachers should focus on using instructional strategies that have been demonstrated to be effective and not technology for technology's sake. Teaching is the creation of environments in which students learn. A central lever point of effective instructional environments is instructional strategies. The implementation of these instructional strategies should be with forethought and with the goals of achieving instructional outcomes at the forefront. A plethora of research (see Bruning, Schraw, \& Norby, 2011) 
delineates effective instructional strategies (such as cooperative learning, problem-based learning, and storytelling) from ineffective instructional strategies (such as learning style alignment and unguided discovery learning). Another corpus of research (see Jonassen, 1996; Mayer, 2005) clarifies how technology may be used to effectively foster student learning. The key to this strategy-technology relationship is to appreciate the supporting role that technology plays in fostering learning, while focusing on the overarching instructional strategies that frame the instruction.

Faculty developers must play a role in helping faculty become aware of the research and mythologies surrounding millennial students and should certainly take care to avoid perpetuating these narratives. Furthermore, faculty developers should promote instructional strategies and technologies that primarily foster learning and are not designed to take advantage of students' nonexistent multitasking abilities. Recognizing the ease with which students can engage in distracting course activities due to technology, the five recommendations for faculty and students should be seen as an outline of a curriculum for a faculty development event targeting those who are struggling with millennial conceptions of students in their courses. Only through active counterengagement with the multitasking mythology can practices that ultimately diminish the learning of our students be changed.

\section{REFERENCES}

Angell, J., \& Moore, A. (1896). Studies from the psychological laboratory of the University of Chicago: 1. Reaction-time: A study in attention and habit. Psychological Revicw, 3, 245-258.

Aratani, L. (2007, February 26). Teens can multitask, but what are the costs?

Washington Post. Retrieved from http://www.washingtonpost.com/ wp-dyn/content/article/2007/02/25/AR2007022501600.html

Barnes, K., Marateo, R. C., \& Ferris, S. P. (2007). Teaching and learning with the Net generation. Innovate: Journal of Online Education, 3(4). Retrieved from http://www.innovateonline.info/pdf/vol3_issue4/Teaching_and_ Learning_with_the_Net_Generation.pdf

Broadbent, D. (1965) Techniques in the study of short-term memory. Acta Psychologica, 24(3), 220-273.

Bruning, R., Schraw, G., \& Norby, M. (2011). Cognitive psychology and instruction. Boston, MA: Pearson.

Carlson, S. (2005, October 7). The Net generation goes to college. Chronicle of Higher Education. Retrieved from http://chronicle.com/article/ The-Net-Generation-Goes-to/12307 
Cassel, E., \& Dallenbach, K. (1918). An objective measure of attributive clearness. American Journal of Psychology, 29(2), 204-207.

Charron, S., \& Koechlin, E. (2010). Divided representation of concurrent goals in the human frontal lobes. Science, 328(5976), 360-363. doi:10.1126/ science. 1183614.

Dede, C. (2005a). Planning for neomillennial learning styles. Educause Quarterly, 28(1), 7-12.

Dede, C. (2005b). Planning for neomillennial learning styles: Implications for investments in technology and faculty. In D. G. Oblinger \& J. L. Oblinger (Eds.), Educating the net generation (pp. 15.1-15.22). Retrieved from http:/www.educause.edu/educatingthenetgen

Dux, P., \& Marois, R. (2009). The attentional blink: A review of data and theory. Attention, Perception, and Psychophysics, 71(8), 1683-1700.

Dux, P., Tombu, M., Harrison, S., Rogers, B., Tong, F., \& Marois, R. (2009). Training improves multitasking performance by increasing the speed of information processing in human prefrontal cortex. Neuron, 63, 127-138.

EDUCAUSE. (2010). About EDUCAUSE. Retrieved from http://www.educause. edu/about

Fitts, P., \& Simon, S. (1952). Some relations between stimulus patterns and performance in a continuous dual-pursuit task. Journal of Experimental Psychology, 4.3(6), 428-436.

Frand, J. L. (2000). The information age mindset: Changes in students and implications for higher education. Educause Review, 35(5), 15-24.

Fried, C. (2008), In-class laptop use and its effects on student learning.

Computers and Education, 50(3), 906-914. doi:10.1016/j. compedu.2006.09.006.

Geissler, L. (1909). The measurement of attention. American journal of Psychology, 20(4), 473-529.

Gustafson, K., \& Branch, R. M. (1997). Instructional design models. Syracuse, NY: ERIC Clearinghouse on Information and Technology.

Hamilton, W., Mansel, H., \& Veitch, J. (1861). Lectures on metaphysics and logic. Edinburgh, UK: William Blackwood \& Sons.

Harel, 1. (1991). Children designers: Interdisciplinary constructions for learning and knowing mathematics in a computer-rich school. Norwood, NJ: Ablex.

Hartman, J., Moskal, P., \& Dziuban, C. (2005). Preparing the academy of today for the learner of tomorrow. In D. G. Oblinger \& J. L. Oblinger (Eds.), Educating the Net generation (pp. 6.1-6.15). Retrieved from http://www .educause.edu/educatingthenetgen

Hiraga, C. Y., Garry, M. I., Carson, R. G., \& Summers, J. J. (2009). Dual-task interference: Atrentional and neurophysiological influences. Bchavioural Brain Research, 20.5(1), 10-18. doi;10.1016/j.bbr.2009.07.019. 
Howe, N., \& Strauss, W. (2000). Millennials rising: The next great generation. New York, NY: Vintage Books.

Hylan, J. (1903). The distribution of attention. Psychological Review, 10(4), 373-403.

Jackson, M. (2008). Distracted: The erosion of attention and the coming dark age. Amherst, NY: Prometheus Books.

Johnson, A., \& Proctor, R. (2004). Attention: Theory and practice. Thousand Oaks, CA: Sage.

Jonassen, D. (Ed.). (1996). Handbook of research for educational communications and technology. New York, NY: Macmillan.

Junco, R., \& Cotten, S. R. (2011). Perceived academic effects of instant messaging use. Computers and Education, 56(2), 370-378. doi:10.1016/j. compedu.2010.08.020.

Kraushaar, J. M., \& Novak, D. C. (2006). Examining the effects of student multitasking with laptops during the lecture. Journal of Information Systems Education, 21(2), 241-252.

Levine, L. E., Waite, B. M., \& Bowman, L. L. (2007). Electronic media use, reading, and academic distractibility in college youth. Cyberpsychology and hehavior, 10(4), 560-566. doi:10.1089/cpb.2007.9990

Levy, J., Pashler, H., \& Boer, E. (2006). Central interference in driving: Is there any stopping the psychological refractory period? Psychological Science, $17(3), 228-235$.

Mangold, K. (2007). Educating a new generation: Teaching baby boomer faculty about millennial students. Nurse Educator, 32(1), 21-23.

Mayer, R. (Ed.). (2005). The Cambridge handbook of multimedia learning. Cambridge, UK: Cambridge University Press.

McGlynn, A. P. (2005). Teaching millennials: Greater need for student-centered learning. Hispanic Outlook in Higher Education, 16(1), 19-20.

Oblinger, D. (2003). Boomers, Gen-Xers, \& millennials: Understanding the new students. Educause Review, 38(4), 37-47.

Ophir, E., Nass, C., \& Wagner, A. (2009). Cognitive control in media multitaskers. Procecdings of the National Academy of Science, 106, 15583-15587.

Oser, K. (2005). Kids cram more hours into media day. Advertising Age, 76(46), 31.

Ostry, D., Moray, N., \& Marks, G. (1976). Attention, practice, and semantic targets. Journal of Experimental Psychology: Human Perception and Performance. 2(3), 326-336.

Palfrey, J., \& Gasser, U. (2008). Born digital: Understanding the first generation of digital natives. New York, NY: Basic Books.

Pashler, H. (1993). Attentional limitations in doing two tasks at the same time. Current Directions in Psychological Science, 1(2), 44-48. 
Pashler, H. (1994). Graded capacity-sharing in dual-task interference? Journal of Experimental Psychology: Human Perception and Performance, 20(2), 330-342.

Pletka, B. (2007). Educating the Net generation: How to engage students in the 21 st century. Santa Monica, CA: Santa Monica Press.

Prensky, M. (2001). Digital natives, digital immigrants, part two: Do they really think differently? On the Horizon, 9(6), 1-6.

Reiser, B. (2004). Scaffolding complex learning: The mechanisms of structuring and problematizing student work. Journal of the Learning Sciences, 13(3), 273-304.

Ruthruff, E., Pashler, H., \& Hazeltine, E. (2003). Dual-task interference with equal task emphasis: Graded capacity sharing or central postponement? Psychonomic Society, 65(5), 801-816.

Saettler, L. P. (1968). A bistory of instructional technology. New York, NY: McGraw-Hill.

Schumacher, E. H., Seymour, T. L., Glass, J. M., Fencsik, D. E., Lauber, E. J., Kieras, D. E., \& Meyer, D. E. (2001). Virtually perfect time sharing in dual-task performance: Uncorking the central cognitive bottleneck. Psychological Science, 12(2), 101-108. Retrieved from http://www.ncbi. nlm.nih.gov/pubmed/11340917

Seidensticker, B. (2006). Futurehype: The myths of technology change. San Francisco, CA: Berrett-Koehler.

Simon, A. E. (2005). The new modus operandi: Techno tasking: Recognizing students' ability to use multiple technologies simultaneously presents a new paradigm. School Administrator, 62(4), 10-13.

Smith, M. (1967). Theories of the psychological refractory period. Psychological Bulletin, 67, 202-213.

Sontag, M. (2009). A learning theory for 21st-century students. Innovate: Journal of Online Education, 5(4). Retrieved from http://www.innovateonline.info/pdf/vol5_issue4/A_Learning_Theory_for_21st-Century_ Students.pdf

Stager, P., \& Zufelt, K. (1972). Dual-task method in determining load differences. Journal of Experimental Psychology, 94(1), 113-11S.

Strayer, D. L., \& Johnston, W. (2001). Driven to distraction: Dual-task studies of simulated driving and conversing on a cellular phone. Psychological Science, 12(6), 462-466.

Tapscott, D. (1998). Growing up digital: The rise of the net generation. New York, NY: McGraw-Hill.

Tapscott, D. (2009). Grown up digital: How the Net generation is changing your world. New York, NY: McGraw-Hill. 
Tombu, M. N., Asplund, C. L., Dux, P. E., Godwin, D., Martin, J. W., \& Marois, R. (2011). A unified attentional bottleneck in the human brain.

Proceedings of the National Academy of Sciences, 108(33), 13426-13431. Tombu, M. N., \& Jolicoeur, P. (2003). A central capacity sharing model of dual task performance. Journal of Experimental Psychology: Human Perception and Performance, 29(1), 3-18.

Van Selst, M., Ruthruff, E., \& Johnston, J. C. (1999). Can practice eliminate the psychological refractory period effect? Journal of Experimental Psychology: Human Perception and Performance, 25, 1268-1283.

Wallis, C. (2006, March 19). The multitasking generation. Time, 48-55.

Welford, A. (1952). The "psychological refractory period" and the review of high speed performance: $A$ review and theory. British Journal of Psychology, 43, 2-19.

Wood, E., Zivcakova, L., Gentile, P., Archer, K., De Pasquale, D., \& Nosko, A. (2012). Examining the impact of off-task multi-tasking with technology on real-time classroom learning. Computers and Education, 58(1), 365374. doi:10.1016/j.compedu.2011.08.029

Zimmerman, B., Bonner, S., \& Kovach, R. (1996). Developing self-regulated learners: Beyond achievement to self-efficacy. Washington, DC: American Psychological Association. 